\title{
Effects of Incorporating Fiber Cocktail on Mechanical Properties of Concrete
}

\author{
Saeed Ahmad ${ }^{1 *}$, Ayub Elahi², Hafiz Waheed Iqbal ${ }^{1}$, and Faiza Mehmood ${ }^{2}$ \\ ${ }^{1}$ Department of Civil Engineering, COMSATS Wah, Pakistan \\ ${ }^{2}$ Civil Engineering Department, UET Taxila, Pakistan
}

\begin{abstract}
The objective of this research work was to determine the effect of fiber cocktail on mechanical properties of concrete. Three types of fibers were used namely monofilament polypropylene fiber, steel fiber and glass fiber. Steel and glass fiber were incorporated in concrete at different dosages while the content of Polypropylene fiber was kept constant. For this purpose, cubes $(150 \times 150 \times 150 \mathrm{~mm})$ and prisms $(101 \times 101 \times 508 \mathrm{~mm})$ were casted for compressive strength test on cubes and Two-Point load test on prisms. Eighteen different mixes were prepared such as control mix, single fiber concrete, double hybrid concrete and triple hybrid concrete. It was observed that both compressive and flexural strength increased with addition of single, double and triple fibers. However, the strengths of triple hybrid concrete were observed to be lesser as compared to single and double hybrid concrete.
\end{abstract}

\section{Introduction}

Concrete has emerged as the material of choice for construction of all type of structures in world today. It is by far the most commonly used construction material [1]. Concrete is inherently weak in tension. Micro cracks begin to initiate in structural elements at about 10$15 \%$ of ultimate load, growing into macro cracks at 25 to $35 \%$ of ultimate load. Therefore, plain concrete members cannot resist large tensile loads unless continuous reinforcing bars are introduced in tensile zone of concrete member. However, the addition of steel bars alone cannot arrest or minimize the developing macro cracks [2]. The addition of randomly distributed short discrete fibers helps in arresting growth of micro cracks which initiate at early stages of loading history [3]. Using single fiber in concrete eradicate only some of unacceptable properties of concrete. It is known that use of one or more different type of fibers in combination would help to improve various properties of concrete [4].

*saeed.ahmad@ciitwah.edu.pk

Most tested fiber combinations are steel-polypropylene [5-9] but other combinations such as steel-glass [10], glass-polypropylene [11]; steel-polyester [12] combinations have also been studied. 
Anand.S worked on determining an appropriate proportion of glass and polypropylene fibers for hybrid concrete. Combining high modulus fibers like nylon, polypropylene with low modulus fibers like steel, glass etc. gives a good hybrid concrete where high modulus fibers improves the strength of concrete while lower modulus fibers enhances strain performance of concrete. Moreover, incorporating heterogeneous types of fibers into concrete makes it homogenous and convert concrete from brittle to ductile [13].

S.C Patodi studied effects of adding steel fibers and polyester fibers in concrete. He concluded from results that the concrete with combination of $0.3 \%$ Recron and $0.7 \%$ steel, yielded $21.91 \%$ increase as compared to plain concrete. This combination of Recron and Steel fibers gave much enhanced strength as compared to steel fiber concrete [14].

Mixing steel and polypropylene fibers make an effective and economical hybrid concrete, which results in reduction of secondary reinforcement. Moreover, hybrid concrete can also be used to resist seismic loads. According to the investigations of Mohankar and Pidurkar, optimum hybrid fiber dosage is $1 \%$ with steel $0.4 \%$ and polypropylene $0.6 \%$ [15].

Combining three types of fibers Steel, polypropylene and PET also gave good results. V. Muthukrishan reported that maximum compressive strength was achieved by combining $0.38 \%$ steel and $0.12 \%$ PET fibers. Generally, an increase of $7 \%$ to $18 \%$ in compressive strength was observed as compared to plain concrete [17].

\section{Experimental Work}

\subsection{Materials Properties}

2.1.1 Cement: ASTM Type-I, Ordinary Portland Cement was used.

2.1.2 Coarse Aggregate: Locally available crushed stone with maximum size of $19 \mathrm{~mm}$ and specific gravity of 2.78 were used as coarse aggregate.

2.1.3 Fine Aggregate: Local pit sand with specific gravity of 2.6 was used as fine aggregate.

2.1.4 Fibers: In this work, steel, glass and polypropylene fibers were used. The properties of fibers provided by manufacturer are given in table-1.

Table 1. Properties of Fibers

\begin{tabular}{|c|c|c|c|}
\hline Property & Steel Fiber & Glass Fiber & $\begin{array}{c}\text { Polypropylene } \\
\text { Fiber }\end{array}$ \\
\hline Density & $7860 \mathrm{~kg} / \mathrm{m}^{3}$ & $2560 \mathrm{~kg} / \mathrm{m}^{3}$ & $900 \mathrm{~kg} / \mathrm{m}^{3}$ \\
\hline Fibre length & $25 \mathrm{~mm}$ & $25 \mathrm{~mm}$ & $12 \mathrm{~mm}$ \\
\hline Fibre diameter & $0.3 \mathrm{~mm}$ & $0.3 \mathrm{~mm}$ & $24 \mathrm{microns}$ \\
\hline Tensile strength & $1100 \mathrm{MPa}$ & $3500 \mathrm{Mpa}$ & $350 \mathrm{MPa}$ \\
\hline Modulus of Elasticity & 205 & 72.5 & 3.45 \\
\hline
\end{tabular}




\subsection{Mix Proportion}

Concrete mix ratio 1:2:4 was adopted to achieve $21 \mathrm{MPa}$ of compressive strength. Specimens with no fibers were named control mix. Total eighteen different mixes were prepared. The detail is given in table 2 and 3.

Table 2. Mix Proportions

\begin{tabular}{|c|c|}
\hline Materials & Quantity \\
\hline Cement & $343 \mathrm{~kg} / \mathrm{m}^{3}$ \\
\hline Fine Aggregates & $689 \mathrm{~kg} / \mathrm{m}^{3}$ \\
\hline Coarse Aggregates & $1378 \mathrm{~kg} / \mathrm{m}^{3}$ \\
\hline Water & $172 \mathrm{Liters}$ \\
\hline Super plasticizer & $8.42 \mathrm{Litters}$ \\
\hline W/C & 0.5 \\
\hline
\end{tabular}

Table3. Volume Fraction of Fibers used in Hybrid Mixes

\begin{tabular}{|c|c|c|c|c|c|c|}
\hline $\begin{array}{l}\text { SR. } \\
\text { No. }\end{array}$ & $\begin{array}{l}\text { Sample } \\
\text { ID }\end{array}$ & & $\begin{array}{l}\text { Volume } \\
\% \quad \text { of } \\
\text { Glass } \\
\text { fibers } \\
\text { (Vfg) }\end{array}$ & $\begin{array}{l}\text { Volume \% of } \\
\text { Polypropylene } \\
\text { fiber (Vfp) }\end{array}$ & $\begin{array}{l}\text { Volume } \\
\% \text { of } \\
\text { Steel } \\
\text { fiber } \\
\text { (Vfs) }\end{array}$ & $\begin{array}{l}\text { Total } \\
\text { Volu } \\
\text { me of } \\
\text { fiber } \\
\text { s(Vf) }\end{array}$ \\
\hline 1 & $\mathrm{CM}$ & $\begin{array}{l}\text { Control } \\
\text { Mix }\end{array}$ & 0 & 0 & 0 & 0 \\
\hline 2 & G1 & \multirow{5}{*}{$\begin{array}{l}\text { Single } \\
\text { Fiber }\end{array}$} & 0.3 & 0 & 0 & 0.3 \\
\hline 3 & G2 & & 0.5 & 0 & 0 & 0.5 \\
\hline 4 & P1 & & 0 & 0.3 & 0 & 0.3 \\
\hline 5 & S1 & & 0 & 0 & 0.3 & 0.3 \\
\hline 6 & S2 & & 0 & 0 & 0.5 & 0.5 \\
\hline 7 & G1P1 & \multirow{8}{*}{$\begin{array}{l}\text { Double } \\
\text { Fiber }\end{array}$} & 0.3 & 0.3 & 0 & 0.6 \\
\hline 8 & G2P1 & & 0.5 & 0.3 & 0 & 0.8 \\
\hline 9 & G1S1 & & 0.3 & 0 & 0.3 & 0.6 \\
\hline 10 & G2S1 & & 0.5 & 0 & 0.3 & 0.8 \\
\hline 11 & S1P1 & & 0 & 0.3 & 0.3 & 0.6 \\
\hline 12 & S2P1 & & 0 & 0.3 & 0.5 & 0.8 \\
\hline 13 & G1S2 & & 0.3 & 0 & 0.5 & 0.8 \\
\hline 14 & G2S2 & & 0.5 & 0 & 0.5 & 1 \\
\hline 15 & G1S1P1 & \multirow{4}{*}{$\begin{array}{l}\text { Triple } \\
\text { Fiber }\end{array}$} & 0.3 & 0.3 & 0.3 & 0.9 \\
\hline 16 & G1S2P1 & & 0.3 & 0.3 & 0.5 & 1.1 \\
\hline 17 & G2S1P1 & & 0.5 & 0.3 & 0.3 & 1.1 \\
\hline 18 & $\mathrm{G} 2 \mathrm{~S} 2 \mathrm{P} 1$ & & 0.5 & 0.3 & 0.5 & 1.3 \\
\hline
\end{tabular}

Note: CM Control Mix, G1- 0.3\% Glass, G2- 0.5\% Glass, S1- 0.3\% Steel, S2$0.5 \%$ Steel, P1- $0.3 \%$ Polypropylene

All the fibers were added by volume of concrete. 


\subsection{Testing Program}

To determine the workability of concrete two types of tests were performed on fresh concrete i.e., Slump Test (ASTM C-143) and Compacting Factor Test (BS1811103).150mm cubes were tested for compressive strength at the age of 28 days in a $3000 \mathrm{KN}$ compression machine as per BS 1881: Part 108,111,116:1983. Prisms were tested for flexural strength under two-point loading in a loading frame as per ASTM C-78-02.

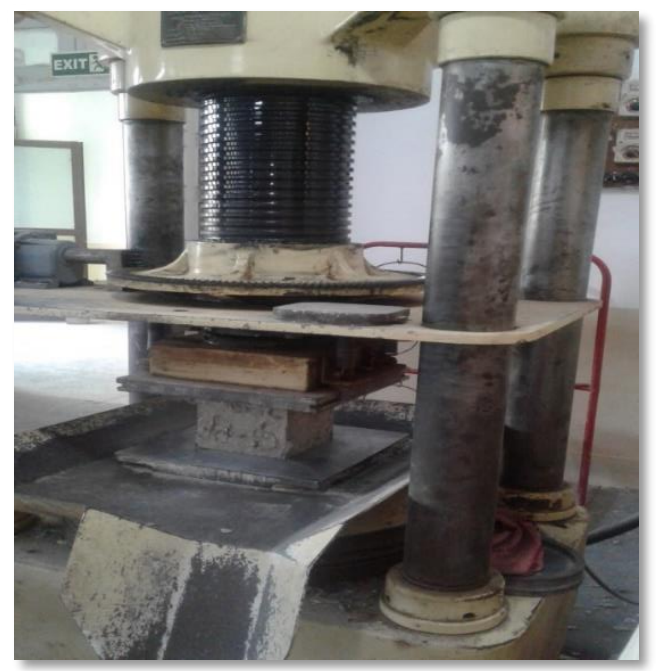

Fig 1 Compression Test on cube

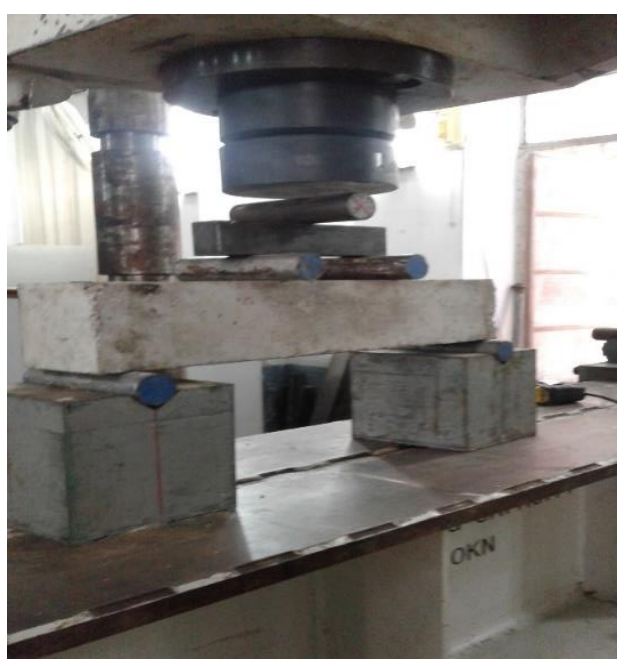

Fig 2 Flexural Strength Test on Prism

\section{Results and Discussion}

\subsection{Workability of Fresh Concrete}

Addition of all types of fibers reduced the workability of concrete. Among all fibrous concrete PPFRC showed less reduction in concrete followed by SFRC and GFRC. Less reduction in workability on addition of polypropylene fibers may be attributed to the hydrophobic nature of fibers due to which polypropylene fibers do not bond with matrix. While due to the geometry of glass fibers they cause interruption to aggregates to freely creep through the adjoining aggregates. Highly stiff fibers make the mix stiffer. The addition of steel and glass fibers in combination reduced the slump to zero.

Table 4 Slump Test Results

\begin{tabular}{|l|l|l|l|l|}
\hline Sample ID & Slump (in) & $\begin{array}{l}\text { Slump } \\
(\mathbf{m m})\end{array}$ & Compacting Factor & $\begin{array}{l}\text { Corresponding } \\
\text { Slump(mm) [18] }\end{array}$ \\
\hline CM & 3 & 76 & 0.95 & $100-175$ \\
\hline G1 & 1 & 25 & 0.88 & $50-100$ \\
\hline G2 & 1.5 & 38 & 0.89 & $50-100$ \\
\hline P1 & 2.5 & 63 & 0.9 & $50-100$ \\
\hline S1 & 2 & 51 & 0.9 & $50-100$ \\
\hline S2 & 2 & 51 & 0.9 & $50-100$ \\
\hline
\end{tabular}




\begin{tabular}{|l|l|l|l|l|}
\hline G1P1 & 1 & 25 & 0.82 & $25-50$ \\
\hline G2P1 & 1 & 25 & 0.82 & $25-50$ \\
\hline G1S1 & 0.5 & 13 & 0.72 & $0-25$ \\
\hline G2S1 & 0 & 0 & 0.7 & $0-25$ \\
\hline S1P1 & 1 & 25 & 0.9 & $50-100$ \\
\hline S2P1 & 0.5 & 13 & 0.9 & $50-100$ \\
\hline G1S2 & 1 & 25 & 0.87 & $25-50$ \\
\hline G2S2 & 0.5 & 13 & 0.86 & $25-50$ \\
\hline G1S1P1 & 0.5 & 13 & 0.8 & $0-25$ \\
\hline G1S2P1 & 0.5 & 13 & 0.8 & $0-25$ \\
\hline G2S1P1 & 0.5 & 13 & 0.84 & $25-50$ \\
\hline G2S2P1 & 0.5 & 13 & 0.83 & $25-50$ \\
\hline
\end{tabular}

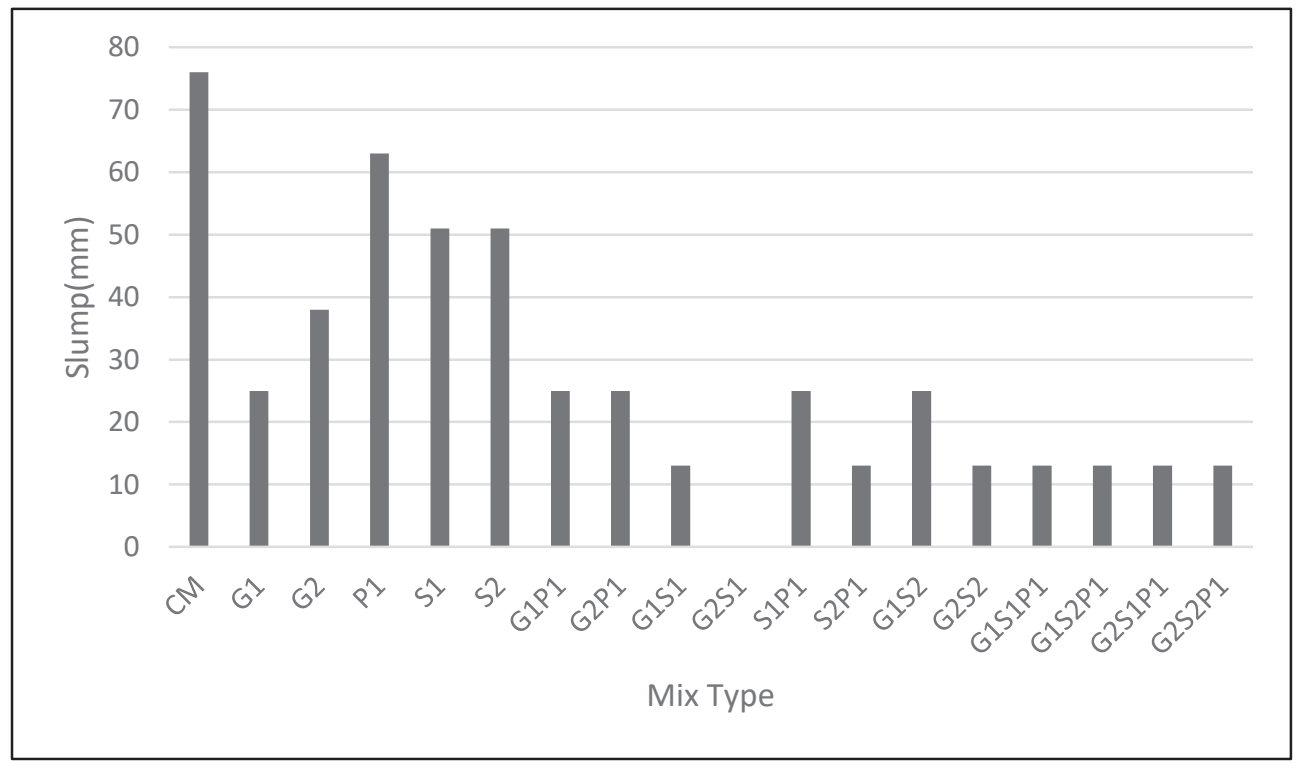

Fig 3 Slump Test Results

\subsection{Compressive Strength Test}

Figure 4-6 show the graphical comparison of 28-days compressive strength of single, double and triple hybrid concretes with control mix. 


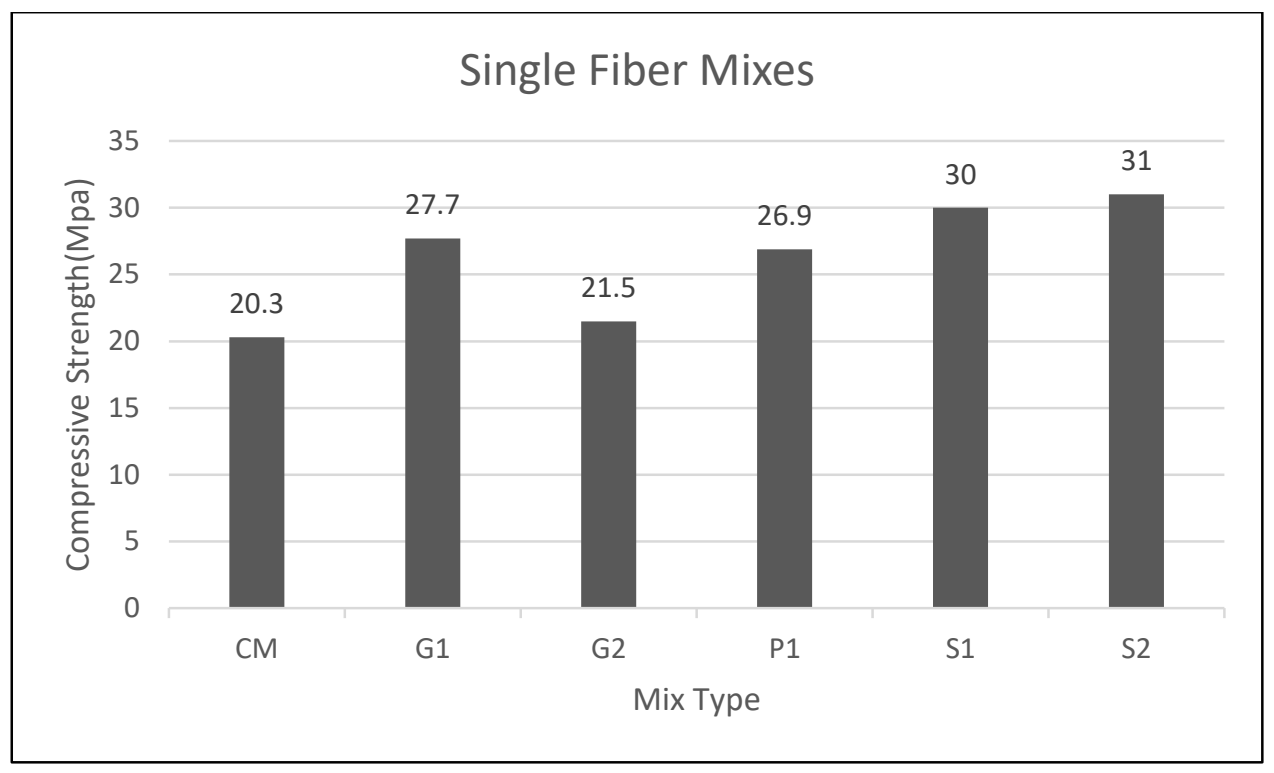

Fig 4 Compressive Strength Results of Single Fiber Mixes

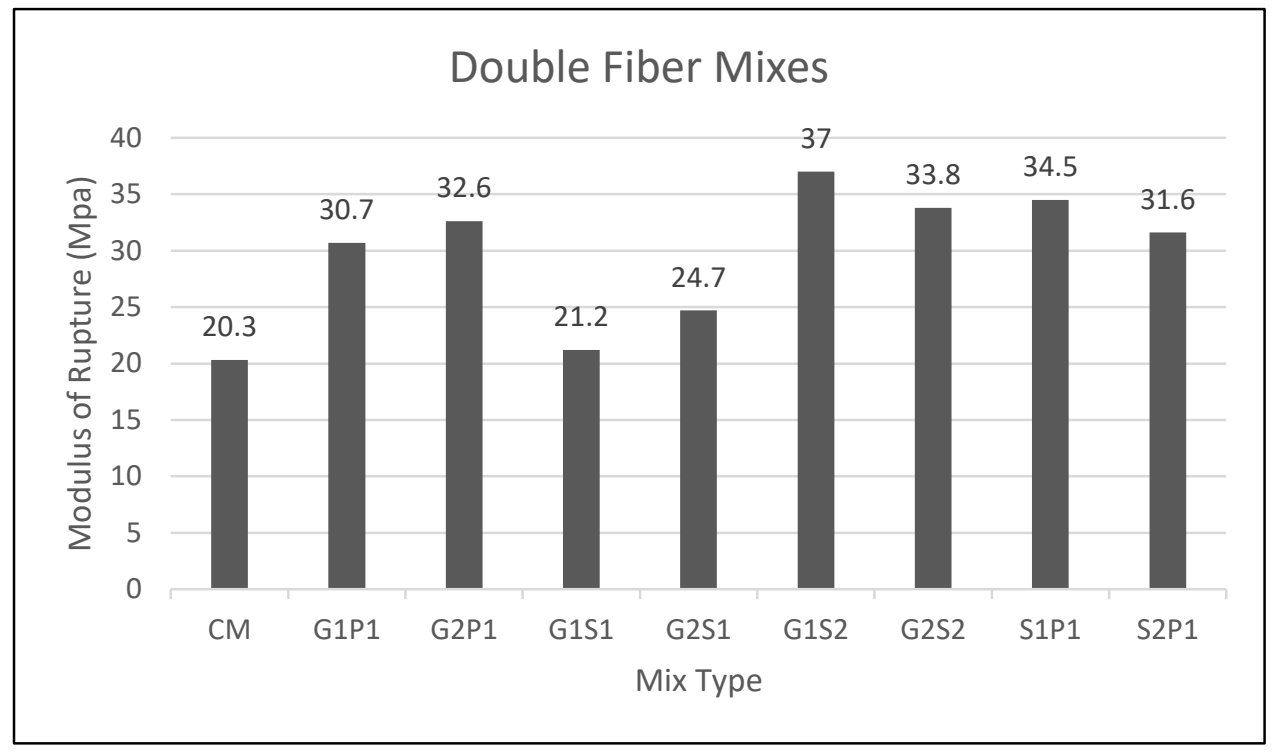

Fig. 5. Compressive Strength Results of Double Hybrid Mix 


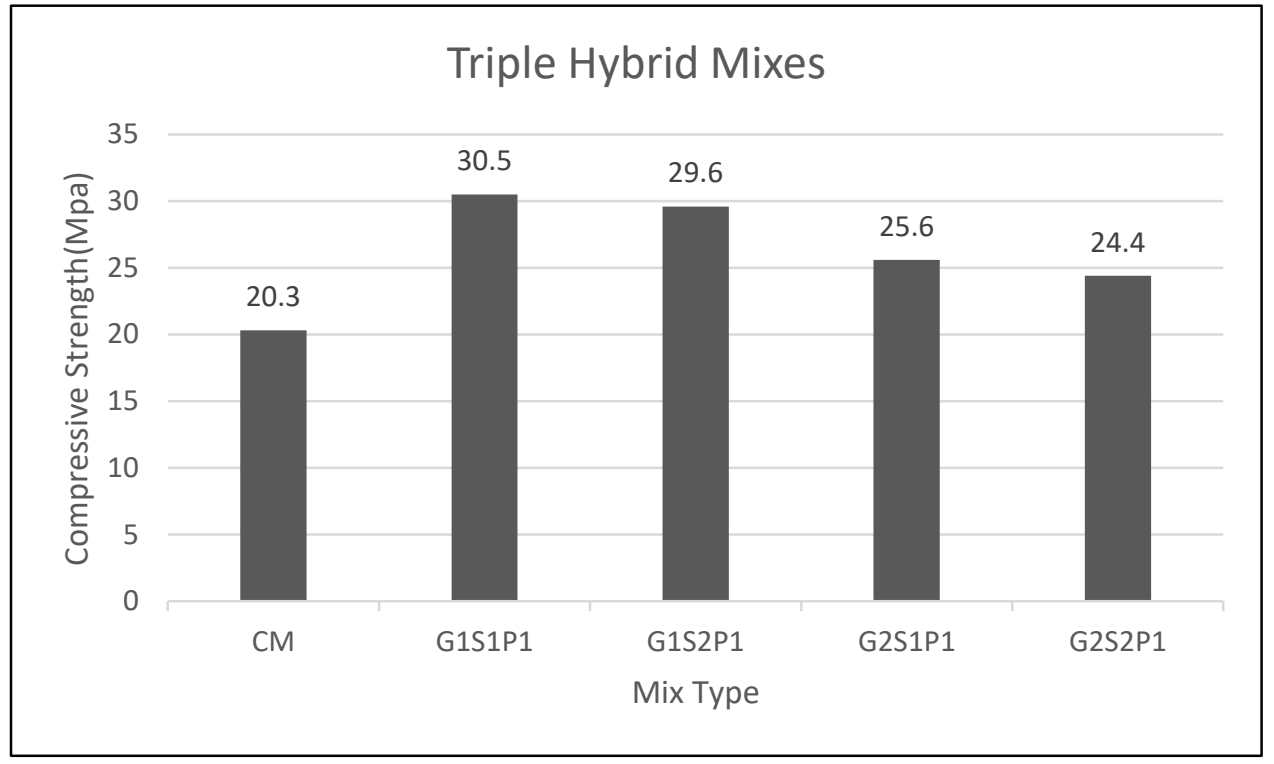

Fig. 6. Compressive Strength Results of Triple Hybrid Mix

All types of fibrous concretes showed an increase in compressive strength as compared to control mix. Increasing glass content beyond $0.3 \%$ decreases compressive strength. This may be due to the clumping of fibers which creates voids in mixing resulting in reduction in strength. Steel fiber being stronger and having high modulus of elasticity exhibit maximum compressive strength amongst all single fiber concretes. Increase in glass fibers also reduced the compressive strength even the steel content was higher. However, with lower glass fiber content and equal amount of steel showed higher compressive strength.

\subsection{Flexural Strength Test}

Figure 7-9 show the graphical comparison of modulus of rupture values of single, double and triple hybrid concrete mixes with control mix.

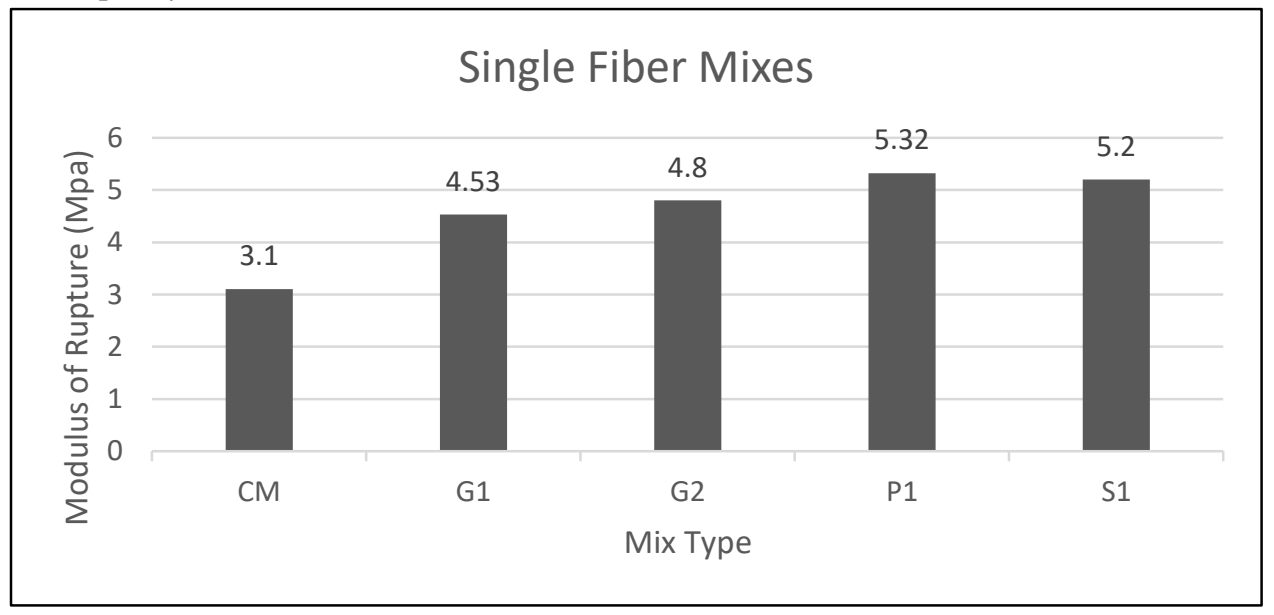

Fig. 7. Flexural Strength Results of Single Fiber Concrete 


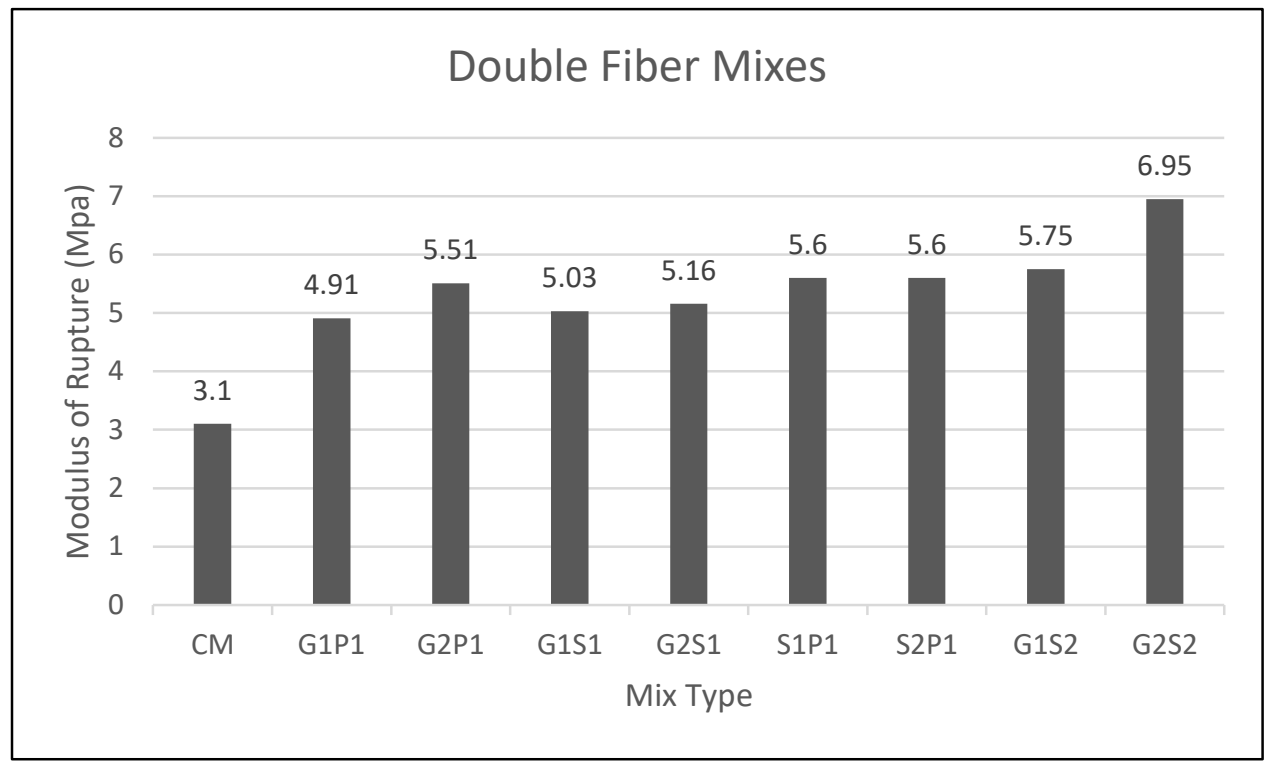

Fig. 8. Flexural Strength Results of Double Hybrid Concrete

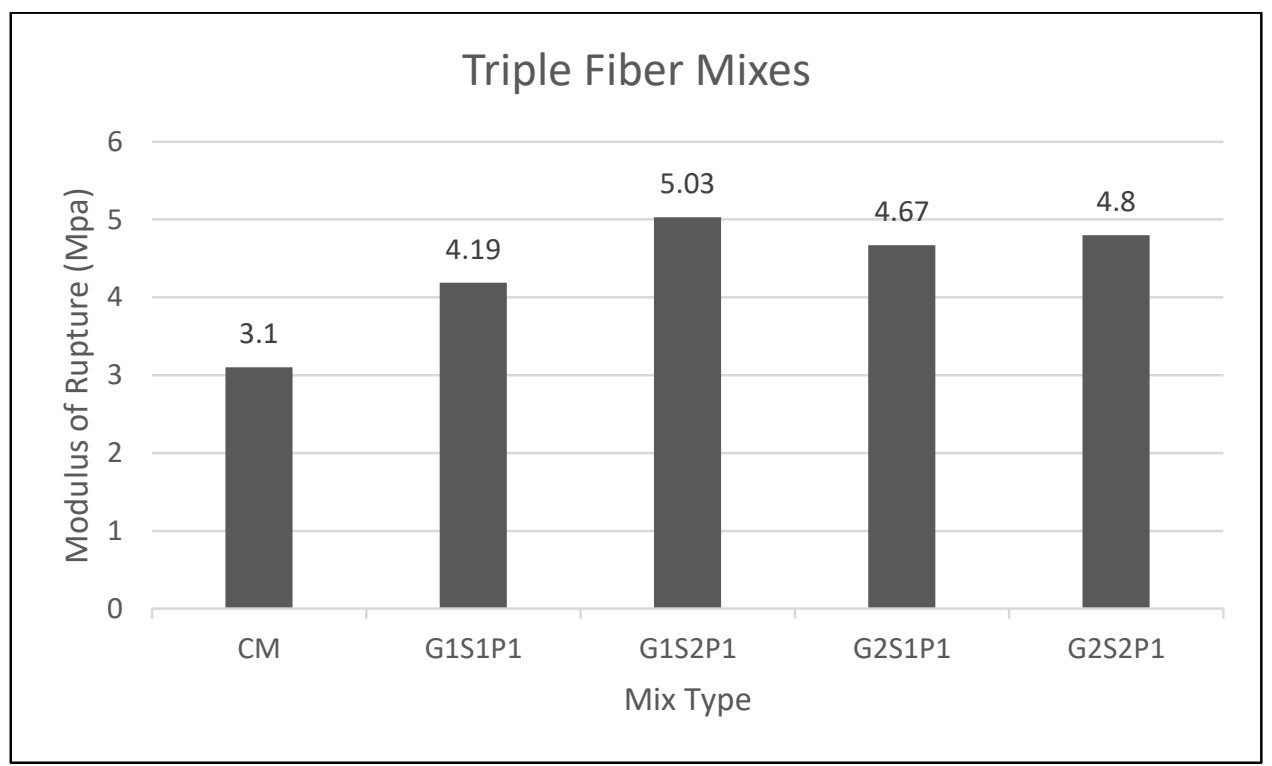

Fig. 9. Flexural Strength Results of Triple Hybrid Concrete

Unlike compressive strength, fibers have comparatively greater effect on flexural strength of concrete. Among Single fiber concretes, PPFRC showed high flexural strength equal to $5.32 \mathrm{MPa}$, followed by steel and glass. Increase in glass fiber content increased the flexural strength. However, a very slight decrease in flexural strength was observed on increasing steel fiber content from $0.3 \%$ to $0.5 \%$. In double hybrid system glass-steel proved to be the best combination followed by steel polypropylene. Steel fiber being stronger and stiffer when combined with glass and polypropylene yielded highest flexural strength. Addition of PP fiber in double hybrid concrete showed adverse effect. PP fiber when added in G2S2 
decreased the strength of resulting mixture by $45 \%$ but it was still $55 \%$ higher than normal mixes.

\section{Conclusions}

1. The addition of fibers reduced the workability of mix.

2. For compressive strength, better results were obtained for double hybrid concrete. Maximum compressive strength was achieved when glass and steel were combined (G1S2) showing $82 \%$ increase in strength as compared to that of control mix. Triple hybrid concrete showed less compressive strength as compared to double and single fiber concrete.

3. From the flexural strength results, it has been observed that fibers have more effect on enhancing flexural strength than compressive strength. Glass-Steel hybrid concrete (G2S2) seems to be the best combination showing 124\% increase in flexural strength as compared to that of control mix.

\section{References:}

1. Soni, PX. and R.Parolkar.2015.Study and Analysis of Durability of Fiber Reinforced Concrete.International Journal of Engineering Sciences and Research Technology v.4, n.6, p.743-750.

2. ACI Committee 544.1996. Fiber Reinforced Concrete, ACI 544.1R, American Concrete Institute, Farmington Hills, MI.

3. Ravi, K. and A.V. Karvekar. 2014.Performance Evaluation of Hybrid Fibre Reinforced Concrete subjected to Freezing and Thawing effect.International Journal of Research in Engineering and Technology v.3, n.11, p.344-347.

4. Vairagade,V.S, K.S.Kene, and N.V.Deshpande. 2012. Investigation of Steel Fiber Reinforced Concrete on Compressive and Tensile Strength. International Journal of Engineering Research \& Technology (IJERT) v.1, n.3, p.1-7.

5. Kumar,M.R, M.Vennila.A, and M.Southamirajan.S. 2013. Experimental Investigation on Hybrid Fibre Reinforced Concrete. International Journal of Emerging Trends in Engineering and Development. v.5,n.9,p.39-45.

6. Qureshi, L.A , M.I. Sheikh, and T. Sultan. 2013. Effect of Mixing Fiber Cocktail on Flexural Strength of Concrete. Procedia Engineering v. 54, p. 711-719.

7. Jadhav, H.S, and M.D.Koli.2013. Flexural Behavior of Hybrid Fiber Reinforced Concrete Beams. International Journal of Structural and Civil Engineering Research v.2,n.3, p. 210-218.

8. Sunita, R.Singh, S.Kumar, and P.Singh. 2016.Strengthening of Concrete by Fibre Reinforcement. International Journal of Enhanced Research in Science, Technology \& Engineering v.5, n.7, p.22-27 .

9 Kumar,S.K, and D.S.Siddiraju.2016.Effect of Steel and Polypropylene Fiber on Mechanical Properties of Concrete.International Journal of Civil Engineering and Technology (IJCIET) v.7, n.3, p. 342-346.

10. Selvi, M.T, and T.S. Thandavamoorthy. 2013. Studies on the Properties of Steel and Polypropylene Fibre Reinforced Concrete without any Admixture. International Journal of Engineering and Innovative Technology (IJEIT) v.3, n.1, p. 411-416. 
11. Satpute, P.C, V.P.Kulkarni, A.J.Mehetre, and M.D.Kokate.2016. Experimental Study on Properties of Concrete By Using Glass And Steel Fibers.International Journal of Latest Engineering Research and Applications (IJLERA) v.01, n.05, p.16-28.

12. Singh,V.K, and D.Kumar.2014.Effect of Fiber on Properties of Concrete. International Journal of Computer \& Mathematical Sciences v.3, n.6, p.111-119.

13. S, Anand, and L. Pammar.2016. Experimental Investigation on Hybrid Fiber Reinforced Concrete. International Journal of Innovative Research in Science,Engineering and Technology v.5,n.9, p.59-65

14. Patodi, S.C, and C.V. Kulkarni. 2012. Performance evaluation of hybrid fiber reinforced concrete matrix. International Journal of Engineering Research and Applications (IJERA)v.2, n.5,p.1856-1863.

15. Mohankar, R.H,M.D.Pidurkar, P.V.Thakre, and S.S. Pakhare. 2016. Hybrid Fibre Reinforced Concrete. International Journal of Science, Engineering and Technology Research (IJSETR)v.5, n.1, p.1-4.

16. V Muthukrishnan, and D. Maruthachalam .2013. Mechanical Properties of Hybrid Fibre Reinforced Concrete With Steel And Synthetic Fibre.International Journal of Engineering Sciences \& Research Technology v.2, n.4, p.899-902

17. E.Kempster. 1968. Pumpable Concrete.Current Paper 26/69, p.8. Building Research Station, Garston. 